\title{
Practitioner Response to Routley, Sargeant and Scaife Paper
}

\begin{abstract}
Jerry Rohrbach, CFRE, ChFC
has more than 35 years experience as a professional fund raiser in both large and small shops. His longest stint of nearly 19 years was with Temple University, Philadelphia as a Director in major gifts and planned giving. In addition to earning is his CFRE certification in 1985, Jerry completed his Chartered Financial Consultant designation (ChFC) in 2000. He is a popular speaker at professional conferences, workshops and round tables on a variety of topics and is a co-founder of Planned Giving Day in Philadelphia. Jerry is an emeritus Board member of the Association of Fundraising Professionals, Greater Philadelphia Chapter having served as President and Chairman of the Board. In 1998 Jerry was elected by his peers as the Fundraising Professional of the Year. He also served on the National Ethics Committee of AFP. Jerry stays involved as a volunteer in the community having served on the Boards of Habitat for Humanity, Philadelphia and The Pennsylvania Bible Society. He earned his bachelor's degree from Philadelphia Biblical University and Master's from Wheaton College in Illinois.
\end{abstract}

International Journal of Educational Advancement (2007) 7, 202-204. doi:10.1057/palgrave.ijea.2150065

\section{Bequest Giving: Some Practical Applications}

Having read the report titled, "Bequests to Educational Institutions: Who Gives and Why?" by Adrian Sargeant, Claire Routley, and Wendy Scaife, I'd like to make a variety of practical observations and applications to this important research. First of all, this study adds confirmation to the importance of the fact that marketing of bequests in our development programs is really the cornerstone, even the foundation of any solid planned giving program. With some relatively rare exception, the majority of total receipts in any given year come from bequests as compared to other planned giving mechanisms. Yet, many of us spend a lion's share of our time and marketing effort promoting what we would perceive to be the hottest planned giving technique at the time, whether this be gift annuities, charitable trusts, or gifts specifically designated from retirement fund assets. In fact, bequest gift receipts in the USA doubled between 1985 and 1995, and then doubled again between 1995 and 2005 according to Giving USA. There is every reason to believe that this trend will continue for at least the next ten years. A marketing program that is regularly and consistently asking the appropriate constituency to consider a bequest to our institutions should steadily yield greater results in the years ahead. Based on this realization, let me make a variety of suggestions:

1. Utilize multiple means to promote bequest giving including a strategic schedule of mailings, newsletters, ads and articles in alumni magazines and/or newsletters, website, and blast emails. 
2. Prospecting for targeted mailings could include:

(a) Reunion classes of the 25th, 50th, and 60th years. Utilize marketing material with strong visuals that show "the way it was" back in $19 x \mathrm{x}$ and the way it is now.

(b) School, college, or department alumni groups selected by graduation year. Individuals who are 50 years old or older are considered the best prospects, but many younger alumni will also make a bequest if encouraged.

(c) Single females and males if they can be identified. For those in this group who are known to have no children, such individuals should be moved to the top of the development officer's list for personal contact.

(d) Long-term, loyal donors who have consistently made any size gift over a 10 -year period or more. It is becoming increasingly understood that longterm loyal donors are often the best-planned giving prospects that yield the greatest returns in marketing efforts. Many of these donors are not on the radar screen for major gifts. As Routley, Seargeant, and Scaife indicate, many of these individuals are low end donors who will never be a large major or annual fund donor, but because of their demonstrated loyalty, make excellent planned giving prospects for testamentary commitments. As we know, testamentary gifts are often the largest gift a donor will make. Also, many frugal millionaires are "hidden" in this group, and the only way to find them is to personally connect with them.

3. At every opportunity, keep asking alumni, parents, faculty/staff, and friends to reveal that they have included your institution in their will or through some other testamentary mechanism such as trusts, qualified retirement plans, and life insurance policies. If you haven't done so recently, utilize an alumni survey as a means to gather this information.

4. Develop a formal "invitation" to join your legacy society that would include a booklet invitation that describes the legacy society and how one can qualify for membership; a response form; and a response envelope-all in a matching package.

5. Develop a well-thought-out recognition program for legacy society members that would include listing members (by class year) in publications, an annual recognition event, and an annual token gift. Focus on this group for personal contact. If you are in a university where there are multiple development officers, take the time to train and encourage these colleagues on how to cultivate these donors.

I'd like to make two final related recommendations. The first is to create a "Book of Expectancies" that would include the names of your legacy society members, what type of planned gift they have indicated, what is the actual or estimated value of their gift and the gift designation, whether the gift is revocable or irrevocable, and whether or not you have any documentation regarding the gift. If you do not know the value of the donor's testamentary intention, then many educational institutions will place a conservative "default" value on these 
based on the average size testamentary gift received over a five-year period. Either the default or actual value of the donor's planned gift should be recorded on the donor's record. If the gift is irrevocable and backed by appropriate documentation, it should be recorded on the donor's gift record. If it is revocable, then it should be recorded in some other appropriate field depending on the software that is being used. Legacy Society members should be a priority donor/ prospect pool of individuals for personal contact by all planned giving and development officers that can assist. The more you personally connect and learn about their testamentary commitments, the stronger your chances of seeing the gift "mature" in the end. A Book of Expectancies is not only a valuable tool to track these commitments, but it also places a reasonable, estimated value on the commitments that you can share with everyone concerned. The more your institution can quantify the value of its planned giving efforts, the better.

Finally, I am a firm believer that planned gifts can and should be tied to gifts for endowment whenever possible. The strongest case for a planned gift is naturally tied to building the future strengths of your educational mission-a legacy for the future that could live on for generations. Named endowments are an excellent means to "give back" and provide for the future while memorializing the donor for generations to come. Such named endowments are commonly funded not only by a donor but also by the donor's family and friends. 